\title{
Vernalization Duration and Light Intensity Influence Flowering of Three Hybrid Nobile Dendrobium Cultivars
}

\author{
Min Lin ${ }^{1}$ and Terri W. Starman ${ }^{2,4}$ \\ Department of Horticultural Sciences, 2133 TAMU, Texas A\&M University, \\ College Station, TX 77843
}

Yin-Tung Wang ${ }^{3}$

Matsui Nursery, 1645 Old Stage Road, Salinas, CA 93908

Genhua Niu²

Texas AgriLife Research at El Paso, Texas A\&M University, El Paso, TX

Additional index words. orchid, Dendrobium nobile, flower induction, flower initiation

\begin{abstract}
The flowering time and flower quality of three hybrid Dendrobium nobile cultivars in relation to light intensity during cooling and duration of vernalization were studied in the first experiment. Mature Dendrobium Red Emperor 'Prince', Den. Sea Mary 'Snow King', and Den. Love Memory 'Fizz' plants were vernalized at $10{ }^{\circ} \mathrm{C}$ under 300 to $350 \mu \mathrm{mol} \cdot \mathrm{m}^{-2} \cdot \mathrm{s}^{-1}$ photosynthetic photon flux $(P P F)(12-h$ photoperiod) or darkness, each with four cooling durations $(2,4,6$, or 8 weeks). Plants were forced in a greenhouse after vernalization. At least 4 weeks of $10{ }^{\circ} \mathrm{C}$ cooling in light was needed for complete flower initiation of Den. Red Emperor 'Prince', whereas Den. Sea Mary 'Snow King' and Den. Love Memory 'Fizz' only needed 2 weeks of $10{ }^{\circ} \mathrm{C}$ cooling regardless of light. For all three cultivars, darkness during vernalization slightly delayed flowering and resulted in fewer but larger flowers. Longer cooling duration delayed flowering, decreased flower longevity, and produced more and larger flowers. In a second experiment, Den. Love Memory 'Fizz' plants were vernalized at $15^{\circ} \mathrm{C}$ for 4 weeks under a 12 -h photoperiod and $P P F$ of $0,50,100$, or $200 \mu \mathrm{mol} \cdot \mathrm{m}^{-2} \cdot \mathrm{s}^{-1}$. Compared with $200 \mu \mathrm{mol} \cdot \mathrm{m}^{-2} \cdot \mathrm{s}^{-1}$, low PPF at 50 or $100 \mu \mathrm{mol} \cdot \mathrm{m}^{-2} \cdot \mathrm{s}^{-1}$ did not affect flowering time or flower qualities; however, darkness delayed flowering and reduced flower qualities except flower diameter.
\end{abstract}

Potted orchids, whose wholesale value reached $\$ 160$ million in 2009, up 26\% from the previous year (U.S. Department of Agriculture, 2010), have become the most valued potted flowering plant in the United States. As a relatively new mass-produced commercial crop, the nobile dendrobiums, hybrids made from Dendrobium nobile, have a high market potential because they produce large amounts of flowers and inflorescences simultaneously (Rotor, 1952). A mature pseudobulb of the nobile dendrobium may have 10 to 15 nodes each with a leaf and an axillary inflorescence that may develop two to six flowers.

The nobile dendrobiums need a period of vernalization after maturation to induce flowering. Ichihashi (1997) reported that $15{ }^{\circ} \mathrm{C}$ chilling was required for flower bud differentiation of nobile-type dendrobium; lack of chilling caused blind buds, aerial shoots, or

Received for publication 11 May 2010. Accepted for publication 24 Aug. 2010.

We thank Matsui Nursery for donation of plant materials.

${ }^{1}$ Graduate Student.

${ }^{2}$ Associate Professor.

${ }^{3}$ Professor (retired). Currently Adjunct Professor, Department of Horticultural Sciences, Texas A\&M University.

${ }^{4}$ To whom reprint requests should be addressed; e-mail tstarman@tamu.edu. no flower formation. Yen et al. (2008) determined that 3 weeks at constant $13{ }^{\circ} \mathrm{C}$ saturates the cooling requirement for Den. Sea Mary 'Snow King'. Conditions such as inadequate vernalization or excessive nutrient supply may cause aerial shoots rather than flowers to form in the leaf axils (Yen, 2008).

Thus, temperature is the most important factor to control flowering of the nobile dendrobium. Rotor (1952) reported that cooling under $18{ }^{\circ} \mathrm{C}$ for 4 months delayed flowering of Dendrobium nobile until Easter; however, plants kept under $13{ }^{\circ} \mathrm{C}$ started to flower in February or March. The Chinese growers start cooling (night temperature is controlled in the 9 to $13{ }^{\circ} \mathrm{C}$ range) from late September or October to advance the flowering time of the nobile dendrobium to meet the New Year and Chinese New Year market time (Li and Wang, 2005). Higher temperature during vernalization and longer cooling durations (up to 6 weeks) were reported to delay flowering of Den. Sea Mary 'Snow King' (Yen et al., 2008). For example, counting from the day cooling starts, Den. Sea Mary 'Snow King' cooled at $18^{\circ} \mathrm{C}$ for 3 weeks took 93 $\mathrm{d}$ and those cooled at $15{ }^{\circ} \mathrm{C}$ for the same duration needed only $80 \mathrm{~d}$ to flower. Plants that received 6 weeks of $15{ }^{\circ} \mathrm{C}$ cooling took 75 $\mathrm{d}$ and those that got 2 weeks of cooling at the same temperature needed only $60 \mathrm{~d}$ to reach flowering.
Response to low temperature in orchid is further complicated by an interaction between temperature and light; thus, light intensity can also be used to manipulate the timing of flowering for the nobile dendrobium. Wang (1995) reported that the number of days in darkness or at a low $P P F$ delayed inflorescence initiation (spiking) of Phalaenopsis orchids by that duration, even when plants were exposed to inductive temperatures. A large-scale test conducted in Taiwan showed that $5 \mathrm{~d}$ of heavy shading (complete darkness or PPF 20 $\mu \mathrm{mol} \cdot \mathrm{m}^{-2} \cdot \mathrm{s}^{-1}$ or less) alternating with $2 \mathrm{~d}$ of light is an effective and inexpensive alternative to heating to a constant $28{ }^{\circ} \mathrm{C}$ for inhibiting Phalaenopsis spiking in commercial operations (Wang et al., 2006). Similarly, the appearance of flower buds in Odontioda and Cymbidium decreased under low light intensity (Kubota et al., 2005; Yamaguchi et al., 1977). Rotor (1952) found that the degree of Cymbidium flower response to low temperature (21 ${ }^{\circ} \mathrm{C}$ ) was determined by light intensity; however, response to low-temperature induction in Dendrobium nobile was unaffected by light.

The results from a preliminary study suggested that unlike Phalaenopsis, which requires adequate light while being cooled to induce spiking, the nobile dendrobium can be cooled in complete darkness to induce flower initiation. Additional research is needed to obtain more data to study if induction in darkness or under low $P P F$ would negatively impact flower quality of the nobile dendrobium. The objective of this study was to determine the effect of light intensity during vernalization and duration of vernalization on the subsequent flower development and quality of the nobile dendrobium.

\section{Materials and Methods}

Expt. 1: Light and cooling duration. Mature plants of three cultivars (the diploid Love Memory 'Fizz', Sea Mary 'Snow King', and tetraploid Red Emperor 'Prince') with an average of 14,11 , and 13 total nodes, respectively, and potted in standard green plastic pots (10.2-cm top diameter, 414-mL vol.), were shipped from Matsui Nursery in Salinas, CA. Sea Mary 'Snow King' and Red Emperor 'Prince' plants arrived at Texas A\&M University, College Station, on 12 Sept. 2008 (2 Jan. 2009 for Love Memory 'Fizz') and were immediately placed in a greenhouse having glass walls and a polycarbonate roof. The root substrate consisted of nine parts of bark mix $(95 \%$ pine bark and $5 \%$ ground sphagnum moss; Bas Van Buuren B.V., De Lier, The Netherlands) to one part long fiber peat (Pindstrup Mosebrug A/S, Ryomgaard, Denmark).

Plants were irrigated with reverse osmosis (RO) water and spaced in every other hole in $30.8 \times 51.4-\mathrm{cm}$ molded polypropylene carrying trays [4.00 Transport Tray (15); Landmark Plastic Corporation, Akron, $\mathrm{OH}$ ] on the greenhouse bench with leaves orienting east and west to best capture the sunlight. To maintain a single pseudobulb per pot, all undesirable secondary shoots were removed when emerged. 
Greenhouse irradiance and air temperature at plant canopy level were recorded every 30 min with a Quantum Light 3 Sensor Bar (Spectrum Technologies, Plainfield, IL) and a WatchDog Data Logger Model 450 (Spectrum Technologies). Plants were grown in a warm greenhouse (Fig. 1) with mean daily temperature ranging from 20 to $25{ }^{\circ} \mathrm{C}$ and a mean photosynthetic daily light integral (DLI) of $9.6 \mathrm{~mol} \cdot \mathrm{m}^{-2} \cdot \mathrm{d}^{-1}$. The automatic thermal screen system was set to be pulled as needed to control the light levels and prevent severe temperature increase in the greenhouse. Pots were irrigated every fourth watering with a nutrient solution made with $\mathrm{RO}$ water and a $15 \mathrm{~N}-2.2 \mathrm{P}-12.5 \mathrm{~K}$ (Peters Excel 15-5-15 Cal-Mag; Scotts, Marysville, $\mathrm{OH}$ ) water-soluble fertilizer at $0.33 \mathrm{~g} \cdot \mathrm{L}^{-1}$. Pesticides azoxystrobin (Heritage; Syngenta Crop Protection, Greensboro, NC) and chlorfenapyr (Pylon; OHP, Mainland, PA) were applied when necessary to control fungus and spider mites, respectively.

The experiment was a $2 \times 4$ factorial with two light intensities during cooling (darkness or 300 to $350 \mu \mathrm{mol} \cdot \mathrm{m}^{-2} \cdot \mathrm{s}^{-1} P P F / 26$ to 30 $\mathrm{mol} \cdot \mathrm{m}^{-2} \cdot \mathrm{d}^{-1}$ of photosynthetic photons) and four cooling durations $(2,4,6$, or 8 weeks). Plants were subjected to cooling treatments in a growth chamber with a mean relative humidity of $75 \%$ starting on 15 Sept. 2008 (15 Jan. 2009 for Love Memory 'Fizz'). One of the growth chambers was totally dark, and the other one had a 12-h photoperiod of 300 to $350 \mu \mathrm{mol} \cdot \mathrm{m}^{-2} \cdot \mathrm{s}^{-1} \mathrm{PPF}$ provided by both fluorescent and incandescent lamps. Plants in each growth chamber were completely randomized for cooling duration with seven or 10 replicates (depending on cultivar) per treatment. The mean air temperatures recorded in the growth chambers were $10.0 \pm 0.2{ }^{\circ} \mathrm{C}$.

Plants were moved back to the greenhouse after the completion of cooling treatments. The mean DLI from the end of cooling until full flowering was $9.0 \mathrm{~mol} \cdot \mathrm{m}^{-2} \cdot \mathrm{d}^{-1}(13.4$ $\mathrm{mol} \cdot \mathrm{m}^{-2} \cdot \mathrm{d}^{-1}$ for Love Memory 'Fizz').

Expt. 2: Effect of light intensity during vernalization. Love Memory 'Fizz' plants in the same 10.2-cm pots arrived at Texas A\&M University, College Station, on 2 Jan. 2009. Growing conditions in the greenhouse before vernalization were the same as those of Expt. 1. The plants were then moved on 15 Jan. 2009 to growth chambers $\left(15^{\circ} \mathrm{C} / 10{ }^{\circ} \mathrm{C}\right.$ day/night, 12-h photoperiod) to induce flower initiation. Four light intensities were given: 1) 200 $\mu \mathrm{mol} \cdot \mathrm{m}^{-2} \cdot \mathrm{s}^{-1}$; 2) $100 \mu \mathrm{mol} \cdot \mathrm{m}^{-2} \cdot \mathrm{s}^{-1}$ covered with one layer of ARMEX Polypropylene Shadecloth 50\% (XS Smith, Red Bank, NJ); 3) $50 \mu \mathrm{mol} \cdot \mathrm{m}^{-2} \cdot \mathrm{s}^{-1}$ covered with two layers of ARMEX Polypropylene Shadecloth 50\%; and 4) darkness covered with one layer Nav-Black Mum Cloth (XS Smith). Cooling was ended after 4 weeks, and plants were transferred into a greenhouse to flower.

Data collection. Date to flowering (when the first flower bud opened); date to full flowering (when all the flower buds opened); flowering node percentage (flowering node number/total nodes); number of aerial shoot, aborted bud, and total flowers; flower diameter (mean diameter of the three largest flowers); flower number per flowering node; flower longevity (duration from the first flower bud opened until this flower wilted); and remaining leaf percentage were collected. The time to flowering was presented from the beginning and the end of cooling.

Statistical analysis. All data were first tested on additivity and normal distribution and then subjected to analysis by GLM and Duncan's multiple range test for comparing the treatment means, all at $P \leq 0.05$. Statistical analysis was performed by SAS 9.2 statistical software (SAS Institute, Cary, NC).

\section{Results}

Expt. 1: Light and cooling duration. Regardless of cooling duration, only $45 \%$ of Red Emperor 'Prince' plants vernalized under darkness flowered compared with $98 \%$ of those cooled in light. However, the flowering percentage of both Sea Mary 'Snow King' and Love Memory 'Fizz' was 100 either under light or in darkness (data not shown).

For Red Emperor 'Prince', significant interactions between light and cooling duration were found on time to flowering. For those cooled under light, longer cooling durations increased the time to flowering from the beginning of cooling, indicating that extending cooling duration could defer flowering (Fig. $2 \mathrm{~A})$. The time to flowering from the end of cold treatment decreased with increased cooling duration (Fig. 2B). Plants that were cooled in darkness needed an extra 5 to $7 \mathrm{~d}$ to reach flowering than plants that were exposed to light, except for those cooled 2 weeks in darkness, which required an especially longer time to flower (Fig. 2A-B). The same interaction was found to affect the time to flowering

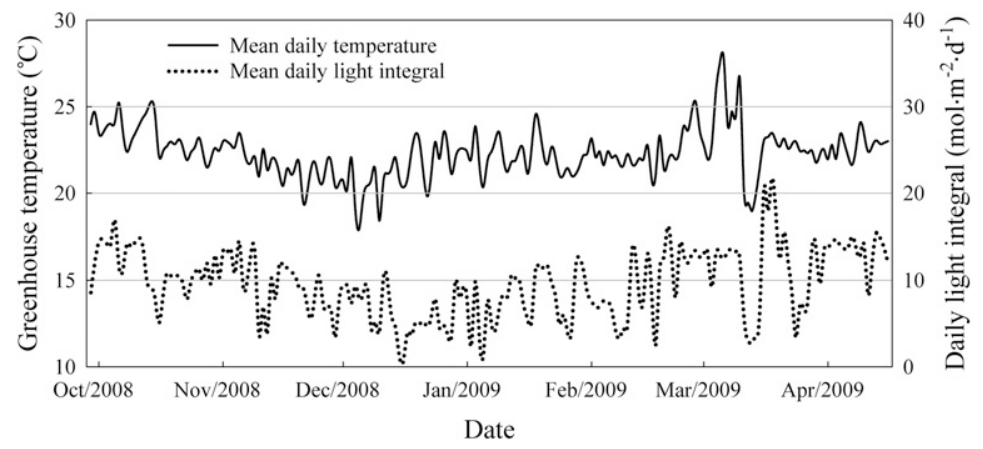

Fig. 1. Mean daily air temperature and light integral of the greenhouse throughout the experimental period (from Sept. 2008 to Apr. 2009) in College Station, TX.

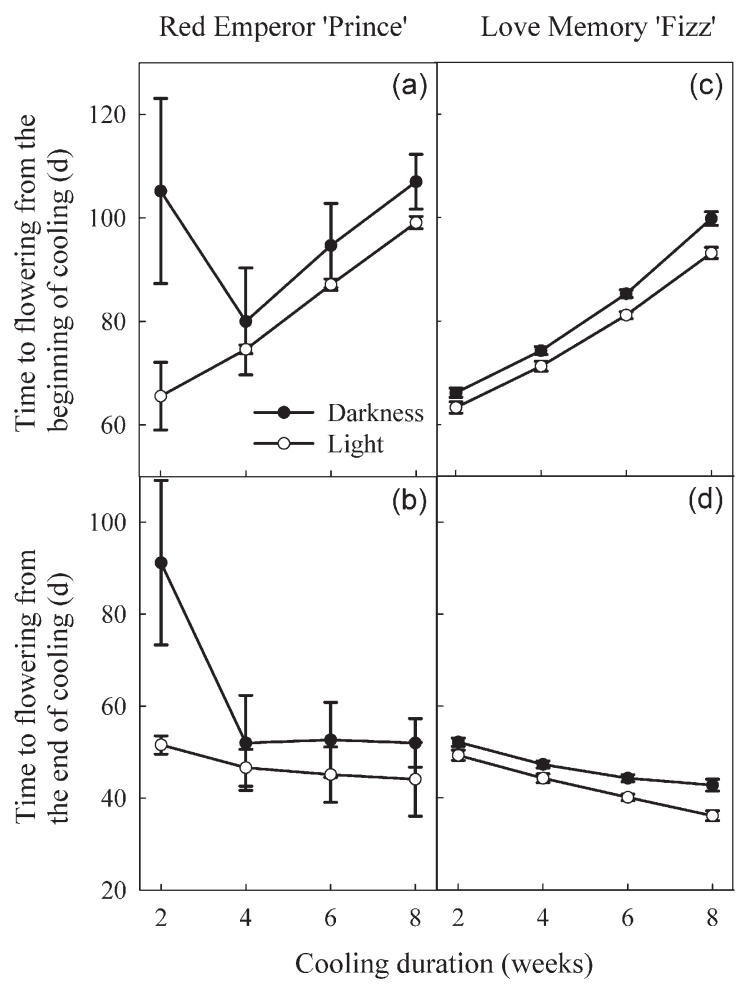

Fig. 2. Effect of light and cooling duration on time required to reach flowering from the beginning or the end of cooling of Dendrobium Red Emperor 'Prince' (A-B) and Den. Love Memory 'Fizz' (C-D). Vertical bars represent $95 \%$ confidence interval. 
of Love Memory 'Fizz'. Extending cooling duration deferred flowering (Fig. 2C) and reduced the time to reach flowering when cooling duration was not counted (Fig. 2D). Regardless of how long the cooling duration was, plants cooled in darkness always required a longer time ( 3 to $6 \mathrm{~d}$ more) to reach flowering compared with those exposed to light (Fig. 2C-D). There was no interaction between light and cooling duration for time to flowering of Sea Mary 'Snow King'. However, the same trends were found as the other two cultivars: darkness during vernalization delayed flowering (by $6 \mathrm{~d}$ ) for this cultivar (Fig. 3). With the increase of cooling duration, time to flowering, including the cooling duration, was extended; however, time to flowering, excluding the cooling duration, was shortened (Table 1; Fig. 3).

Light and cooling duration interactively affected the total flower number of Red Emperor 'Prince'. Plants that were cooled under light always produced more flowers than those cooled in darkness. Plants cooled for 2 weeks in light or darkness produced fewer than five flowers per plant (Fig. 4). Regardless of light treatment, Sea Mary 'Snow King' cooled for 2 weeks produced fewer but larger flowers compared with those that received other cooling durations (Table 1; Fig. 3). For both Sea Mary 'Snow King' and Love Memory 'Fizz', the presence of light during vernalization increased the flowering node percentage by at least 22, producing more but slightly smaller flowers. In addition, plants exposed to darkness during cooling had more non-flowering nodes on both ends of the pseudobulb (Table 2; Fig. 3).

Longer cooling durations reduced the flower longevity for all three cultivars. Flowers of Red Emperor 'Prince' and Sea Mary 'Snow King' lasted 10 d longer when cooled for 2 weeks compared with those cooled for 8 weeks. Love Memory 'Fizz' had longer flower longevity than the other two cultivars; flowers cooled for 2 weeks lasted more than $24 \mathrm{~d}$ longer compared with those receiving 8 weeks cooling treatment (Table 3 ).

For Red Emperor 'Prince' and Love Memory 'Fizz', regardless of light, the percentage of remaining leaves decreased when the cooling duration increased (Fig. 5A). For Red Emperor 'Prince' and Sea Mary 'Snow' King, regardless of cooling duration, darkness treatment increased the leaf drop (Fig. 5B). In addition, Red Emperor 'Prince' was more susceptible to losing leaves compared with the other two cultivars (Fig. 5A-B).

Expt. 2: Effect of light intensity during vernalization. Compared with 200 and 100 $\mu \mathrm{mol} \cdot \mathrm{m}^{-2} \cdot \mathrm{s}^{-1}, 50 \mu \mathrm{mol} \cdot \mathrm{m}^{-2} \cdot \mathrm{s}^{-1}$ slightly increased flower diameter. However, the various light intensities, darkness excluded, did not affect time to flowering, time to full flowering, or flower qualities, including flowering node percentage, total flower number, and flower longevity. Consistent with Expt. 1 (Table 2), darkness treatment deferred time to flowering, resulted in lower flowering node percentage, reduced total flower number, and increased flower diameter. In addition, plants exposed to (a) Sea Mary 'Snow King'

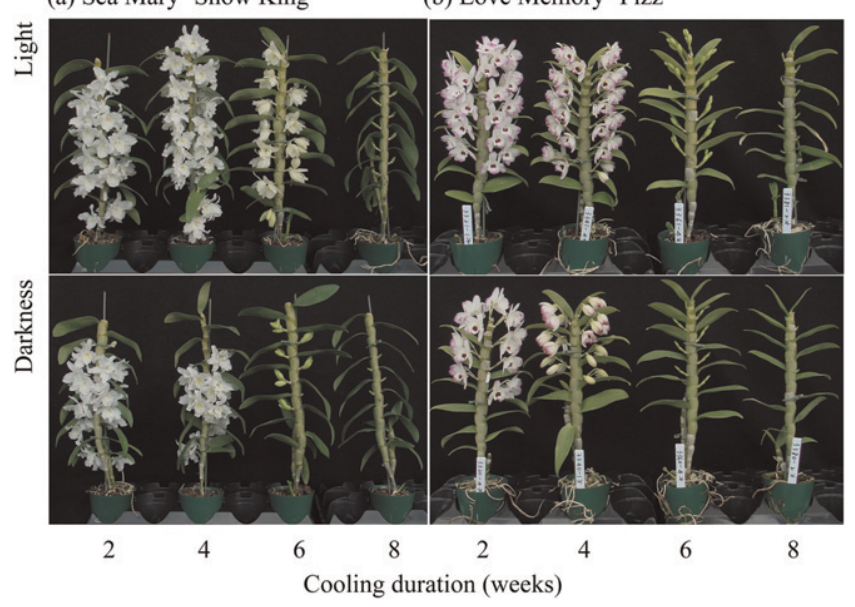

Fig. 3. Visual performance with various cooling durations and light conditions (A) of Dendrobium Sea Mary 'Snow King', on 14 Dec. 2008, 13 weeks after initiation of vernalization and (B) of Den. Love Memory 'Fizz', on 30 Mar. 2009, 10 weeks after initiation of vernalization.

Table 1. Effect of cooling duration, regardless of light, on time to flowering from the beginning of cooling, time to flowering from the end of cooling, total flower number, and flower diameter of Den. Sea Mary 'Snow King'.

\begin{tabular}{lcccc}
\hline $\begin{array}{l}\text { Cooling } \\
\text { duration (weeks) }\end{array}$ & $\begin{array}{c}\text { Time to flowering } \\
\text { from the beginning of } \\
\text { cooling }(\mathrm{d})\end{array}$ & $\begin{array}{c}\text { Time to flowering from } \\
\text { the end of cooling }(\mathrm{d})\end{array}$ & $\begin{array}{c}\text { Total flower } \\
\text { number }\end{array}$ & $\begin{array}{c}\text { Flower diam } \\
(\mathrm{cm})\end{array}$ \\
\hline 2 & $67.8 \mathrm{~d}^{\mathrm{z}}$ & $53.8 \mathrm{a}$ & $19.2 \mathrm{~b}$ & $7.8 \mathrm{a}$ \\
4 & $76.3 \mathrm{c}$ & $48.3 \mathrm{~b}$ & $27.1 \mathrm{a}$ & $7.5 \mathrm{ab}$ \\
6 & $89.2 \mathrm{~b}$ & $47.2 \mathrm{~b}$ & $24.8 \mathrm{a}$ & $7.5 \mathrm{ab}$ \\
8 & $101.5 \mathrm{a}$ & $46.5 \mathrm{~b}$ & $26.3 \mathrm{a}$ & $7.4 \mathrm{~b}$ \\
\hline
\end{tabular}

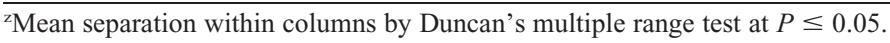

darkness during vernalization in this experiment needed 10 more $\mathrm{d}$ to reach full flowering and had $\approx 8 \mathrm{~d}$ shorter flower longevity (Table 4).

\section{Discussion}

Nobile dendrobium requires a critical amount of thermal time (degree-days) for a vernalization response. In this study, we used three nobile dendrobium cultivars and cooled them for 2 and 4 weeks to span the 3 weeks' exposure, which was reported to be the critical vernalization period for Den. Sea Mary 'Snow King' cooled at $13^{\circ} \mathrm{C}$ by Yen et al. (2008). For Den. Sea Mary 'Snow King', aerial shoots or aborted buds were produced instead of flower buds when the amount of cooling was below the critical amount. Above the critical amount, flowers were produced but higher amounts of cooling delayed flowering time and affected flower quality (Yen et al., 2008). Our results differed in that we did not encounter the formation of aerial shoots among cooling treatments. Wang and Starman (2008) found that tetraploid varieties may need a longer duration of cooling to induce flower initiation. We found that Den. Red Emperor 'Prince' required at least 4 weeks of cooling to flower well. Plants that were cooled for 2 weeks took more time to reach flowering and produced fewer flowers than those that were cooled for 4 weeks or longer, suggesting that Red Emperor 'Prince', being a tetraploid variety, needs more cooling for improved flower initiation than the

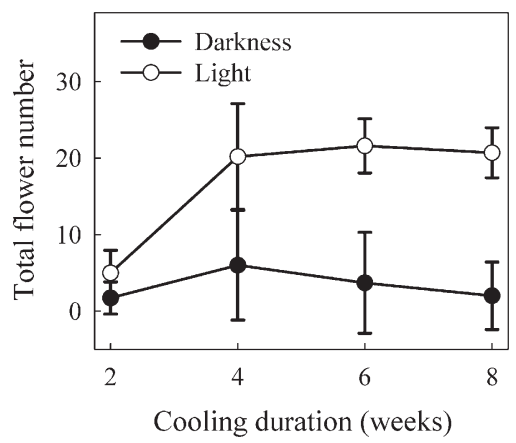

Fig. 4. Effect of light and cooling duration on total 'Prince'. Vertical bars represent $95 \%$ confidence interval.

diploid varieties Den. Sea Mary 'Snow King' and Den. Love Memory 'Fizz'.

Rotor's (1952) study on Dendrobium nobile suggested that light did not affect flower induction. However, in this study, we found that in addition to the amount of cooling, light intensity during vernalization is shown to be another factor that influences flower quality and timing of the nobile dendrobium, and this effect is cultivar-dependent. Without light during vernalization, few flower buds initiated for Red Emperor 'Prince'. For Sea Mary 'Snow King' and Love Memory 'Fizz', 25\% fewer flower buds were produced when cooled in darkness compared with those receiving light treatments, indicating that the flower number of Dendrobium Red Emperor 
light requirement for flower initiation for these two cultivars is facultative, not obligate. Consequently, light was not required for flower induction in the three dendrobium nobile cultivars used in this study but may be needed for more complete flower development and more uniform flowering, especially for Red Emperor 'Prince'. Thus, we recommend at least 4 weeks of $10^{\circ} \mathrm{C}$ cooling in light for Red Emperor 'Prince' and at least 2 weeks of $10^{\circ} \mathrm{C}$ cooling regardless of light for Sea Mary 'Snow King' or Love Memory 'Fizz' to achieve complete vernalization. From a practical point of view, vernalization of Den. Sea Mary 'Snow King' and Love Memory 'Fizz' in the dark would be simpler and less expensive for growers.

Dendrobium Hinde 'Toutenkou' had fewer flowers on the upper nodes under inducing temperature. Ichihashi (1997) suggested that the upper nodes that were not fully mature did not respond to low temperature. We found that when cooled in darkness, flowers were mainly concentrated in the middle of the pseudobulb for Sea Mary 'Snow King' and Love Memory 'Fizz', indicating that bud maturity could be one of the factors that affect flower initiation. Compared with the less mature (top) buds, the more mature buds (in the middle of the pseudobulb) were easier to be induced by low

Table 2. Effect of light, regardless of cooling duration, on flowering node percentage, total flower number, flower diameter, number of nodes without flower on top, and bottom of pseudobulbs of Dendrobium Sea Mary 'Snow King' and Den. Love Memory 'Fizz'.

\begin{tabular}{llccccc}
\hline Dendrobium & \multicolumn{1}{c}{$\begin{array}{c}\text { Light } \\
\text { cultivar }\end{array}$} & $\begin{array}{c}\text { Flowering node } \\
\text { percentage } \\
(\%)\end{array}$ & $\begin{array}{c}\text { Total } \\
\text { flower } \\
\text { number }\end{array}$ & $\begin{array}{c}\text { Flower } \\
\text { diam } \\
(\mathrm{cm})\end{array}$ & $\begin{array}{c}\text { Node without } \\
\text { flower } \\
\text { (top) }\end{array}$ & $\begin{array}{c}\text { Node without } \\
\text { flower } \\
\text { (bottom) }\end{array}$ \\
\hline Sea Mary 'Snow King' & Light & $74.9 \mathrm{a}^{\mathrm{z}}$ & $29.7 \mathrm{a}$ & $7.4 \mathrm{~b}$ & $1.2 \mathrm{~b}$ & $2.0 \mathrm{~b}$ \\
& Darkness & $48.0 \mathrm{~b}$ & $19.0 \mathrm{~b}$ & $7.7 \mathrm{a}$ & $2.8 \mathrm{a}$ & $3.3 \mathrm{a}$ \\
Love Memory 'Fizz' & Light & $71.4 \mathrm{a}^{\mathrm{z}}$ & $37.0 \mathrm{a}$ & $6.1 \mathrm{~b}$ & $0.4 \mathrm{~b}$ & $3.8 \mathrm{~b}$ \\
& Darkness & $48.7 \mathrm{~b}$ & $23.7 \mathrm{~b}$ & $6.5 \mathrm{a}$ & $1.0 \mathrm{a}$ & $6.0 \mathrm{a}$ \\
\hline
\end{tabular}

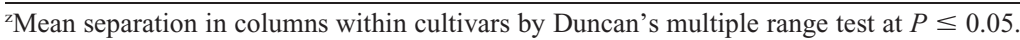

Table 3. Effect of cooling duration, regardless of light, on flower longevity of Dendrobium Red Emperor 'Prince', Den. Sea Mary 'Snow King', and Den. Love Memory 'Fizz'.

\begin{tabular}{lccc}
\hline $\begin{array}{l}\text { Cooling duration } \\
\text { (weeks) }\end{array}$ & \multicolumn{3}{c}{ Flower longevity (d) } \\
\cline { 2 - 4 } & Red Emperor 'Prince' & Sea Mary 'Snow King' & Love Memory 'Fizz' \\
\hline 2 & $38.3 \mathrm{a}^{\mathrm{z}}$ & $39.1 \mathrm{a}$ & $61.4 \mathrm{a}$ \\
6 & $32.6 \mathrm{~b}$ & $37.3 \mathrm{a}$ & $54.0 \mathrm{a}$ \\
8 & $26.2 \mathrm{c}$ & $30.8 \mathrm{~b}$ & $41.6 \mathrm{~b}$ \\
\hline
\end{tabular}

${ }^{\mathrm{z}}$ Mean separation within columns by Duncan's multiple range test at $P \leq 0.05$.

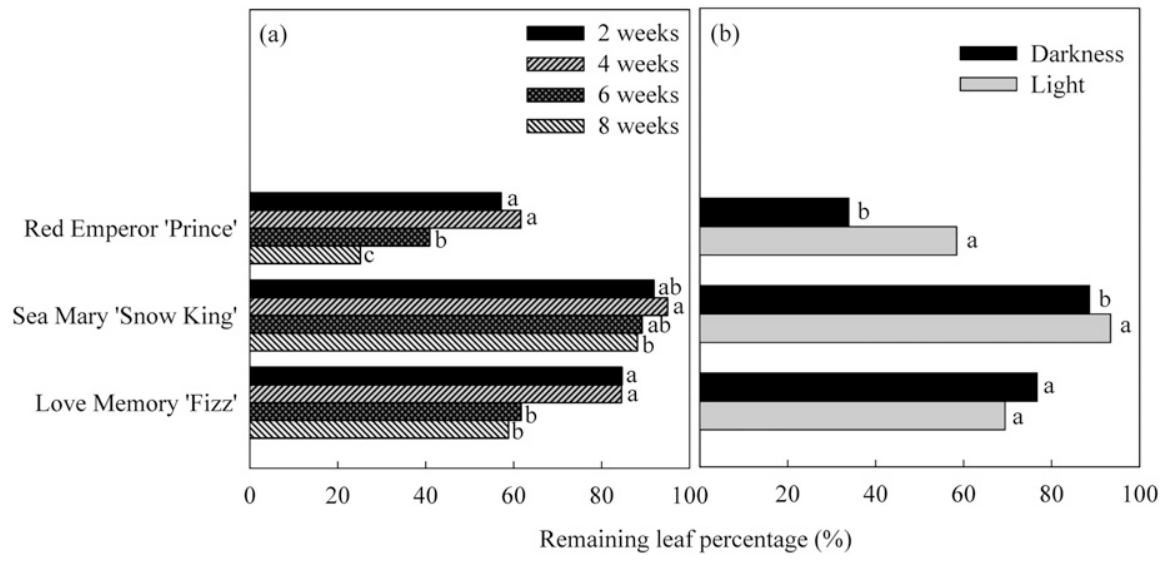

Fig. 5. Remaining leaf percentage of Dendrobium Red Emperor 'Prince', Den. Sea Mary 'Snow King', and Den. Love Memory 'Fizz'. (A) Effect of cooling duration regardless of light and (B) effect of light regardless of cooling duration. temperature under darkness. Plants cooled in darkness produced slightly larger flowers than those in light, which could be attributed to fewer flowers and relatively more nutrients being allocated to each flower.

As long as flower buds are initiated, the subsequent floral development is mainly affected by temperature. Lowering the temperature reduces respiration and other biochemical activities as well as floral development (Hew and Yong, 2004). This could explain our results that longer cooling duration deferred flowering, which is consistent with the findings of Yen et al. (2008). Thus, we recommend that growers adjust cooling duration to defer flowering of nobile dendrobium from Valentine's to Mother's Day to increase their marketing window. Rotor (1952) found that flower bud development may be hastened by the use of artificial lights to supplement natural daylight, and Ichihashi (1997) reported that high light and longer irradiation promote flower bud development. In this study, darkness during vernalization slightly delayed flowering of Sea Mary 'Snow King' and Love Memory 'Fizz', suggesting that covering the greenhouse by black cloth could be another strategy for growers to defer flowering of these cultivars.

Shorter flower longevity under longer cooling duration in this study probably attributes to the stress of low temperature that the plants underwent. However, compared with the potential market reward obtained by flowering control, slightly shorter longevity could be an acceptable sacrifice. Further experimentation could investigate how to optimize the cooling duration after flower initiation to delay flowering without reducing flower longevity. Ketsa et al. (2001) reported that carbohydrate levels affected the life of open florets and compared with the tetraploid line, the shorter vase life of cut diploid Den. 'Caesar' was the result of their high respiration rate. However, in our study, Red Emperor 'Prince' (tetraploid) had similar flower longevity to Sea Mary 'Snow King' (diploid) and much shorter flower longevity than Love Memory 'Fizz' (diploid). Because potted plants were used in this study, carbohydrate level may not be the limiting factor for flower senescence as it is with cut flowers.

The American Orchid Society (2002) reported that temperatures below $10{ }^{\circ} \mathrm{C}$ may cause leaf abscission in some orchid species. Low day temperature caused leaf yellowing and defoliation of Den. Snowflake 'Red Star' (Sinoda et al., 1984, 1985). Wang (1995) reported that Phalaenopsis cooled in complete darkness for 6 weeks dropped an average of one leaf per plant compared with those cooled under light. These results were in agreement

Table 4. Effect of light intensity during vernalization on time to flowering from the end of cooling, time to full flowering, flowering node percentage, total flower number, flower diameter, and flower longevity of Dendrobium Love Memory 'Fizz'.

\begin{tabular}{|c|c|c|c|c|c|c|}
\hline $\begin{array}{l}\text { Light intensity } \\
\left(\mu \mathrm{mol} \cdot \mathrm{m}^{-2} \cdot \mathrm{s}^{-1}\right)\end{array}$ & $\begin{array}{l}\text { Time to flowering from the } \\
\text { end of cooling }(\mathrm{d})\end{array}$ & $\begin{array}{l}\text { Time to full } \\
\text { flowering }(\mathrm{d})\end{array}$ & $\begin{array}{l}\text { Flowering node } \\
\text { percentage }(\%)\end{array}$ & $\begin{array}{c}\text { Total flower } \\
\text { number }\end{array}$ & $\begin{array}{l}\text { Flower diam } \\
(\mathrm{cm})\end{array}$ & $\begin{array}{l}\text { Flower longevity } \\
\text { (d) }\end{array}$ \\
\hline 0 (darkness) & $52.5 \mathrm{a}$ & $15.3 \mathrm{a}$ & $38.8 \mathrm{~b}$ & $15.6 \mathrm{~b}$ & $7.6 \mathrm{a}$ & $41.8 \mathrm{~b}$ \\
\hline 50 & $45.5 \mathrm{~b}$ & $5.5 \mathrm{~b}$ & $61.8 \mathrm{a}$ & $27.4 \mathrm{a}$ & $6.9 \mathrm{~b}$ & $50.1 \mathrm{a}$ \\
\hline 100 & $45.6 \mathrm{~b}$ & $6.0 \mathrm{~b}$ & $65.8 \mathrm{a}$ & $32.5 \mathrm{a}$ & $6.4 \mathrm{c}$ & $52.0 \mathrm{a}$ \\
\hline 200 & $43.8 b^{z}$ & $5.8 \mathrm{~b}$ & $71.5 \mathrm{a}$ & $31.1 \mathrm{a}$ & $6.4 \mathrm{c}$ & $50.9 \mathrm{a}$ \\
\hline
\end{tabular}

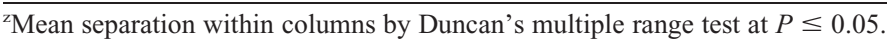


with our findings of leaf abscission on Red Emperor 'Prince'. Consumers in the United States and Europe prefer green foliage on flowering nobile dendrobium plants (Wang and Starman, 2008). As a result, keeping proper nutrient application to retain the foliage in a healthy and attractive condition is important to obtaining products that are preferred by the consumers.

Our study shows that light intensity during vernalization does not substantially affect flowering time and most of the flower quality attributes of these nobile dendrobium cultivars. Thus, for the growers in cool or mild climates, such as in Salinas, CA, vernalization requirement of dendrobium nobile can be achieved in a shaded greenhouse without the cost for coolers.

\section{Literature Cited}

American Orchid Society. 2002. Dendrobium: The American Orchid Society culture sheets, 5 Apr. 2010. <http://www.mikes-orchids.com/dendrobe. pdf $>$.

Hew, C.S. and J.W.H. Yong. 2004. The physiology of tropical orchids in relation to the industry. 2nd Ed. World Scientific Publishing Co. Pte. Ltd., Singapore.

Ichihashi, S. 1997. Orchid production and research in Japan, p. 171-212. In: Arditti, J. and A.M. Pridgeon (eds.). Orchid biology: Reviews and perspectives, VII. Kluwer Academic Publishers, Dordrecht, The Netherlands.

Ketsa, S., A. Uthairatanakij, and A. Prayurawong. 2001. Senescence of diploid and tetraploid cut inflorescences of Dendrobium 'Caesar'. Sci. Hort. 91:133-141.

Kubota, S., J. Yamamoto, Y. Takazawa, H. Sakasai, K. Watanabe, K. Yoneda, and N. Matsui. 2005. Effects of light intensity and temperature on growth, flowering, and single-leaf $\mathrm{CO}_{2}$ assimilation in Odontioda orchid. J. Jpn. Soc. Hort. Sci. 74:330-336.

Li, Z. and Y. Wang. 2005. The flowering control of nobile-type dendrobium. China Flowers and Hort. 8:20-24 [in Chinese].

Rotor, G.B.J. 1952. Daylength and temperature in relation to growth and flowering of orchids. Cornell Agr. Expt. Sta. Bul. 885:1-47.

Sinoda, K., M. Hara, and M. Aoki. 1984. Growth and flowering control in Dendrobium. (4) Cold treatments and flowering. Abstr. Jpn. Soc. Hort. Sci. Spring Meet. p. 364-365 [in Japanese].

Sinoda, K., M. Hara, and M. Aoki. 1985. Growth and flowering control in Dendrobium. (5) The effects of day and night temperature during cold treatment on development of lateral buds. Abstr. Jpn. Soc. Hort. Sci. Autumn Meet. p. 396-397 [in Japanese].

U.S. Department of Agriculture. 2010. Floriculture crops 2009 summary. U.S. Dept. Agr., Washington, DC.

Wang, Y.T. 1995. Phalaenopsis orchid light requirement during the induction of spiking. HortScience 30:59-61.

Wang, Y.T. and T. Starman. 2008. The nobile dendrobium. ICOGO Bul. 2:12-13.

Wang, Y.T., W.T. Tsai, and T.E. Dai. 2006. Heavy shading-An effective, low-cost alternative to high temperature for inhibiting spiking in Phalaenopsis. Proc. 2006 Taiwan Intl. Orchid Symp. p. 164-173.

Yamaguchi, S., T. Kataoka, and T. Nakano. 1977. Studies on the flowering of Cymbidium. 4. Bull. Mie Agric. Tech. Center 6:67-72.

Yen, C.Y.T. 2008. Effects of nutrient supply and cooling on growth, flower bud differentiation, and propagation of the nobile dendrobium orchid. MS thesis Texas A\&M Univ., College Station, TX.

Yen, C.Y.T., T.W. Starman, Y.T. Wang, and G. Niu. 2008. Effect of cooling temperature and duration on flowering of the nobile dendrobium orchid. HortScience 43:1765-1769. 